\title{
Serious infections in JIA patients upon MTX, TFN inhibitors and combinations
}

\author{
Gerd Horneff $^{1 *}$, Ingrid Becker ${ }^{2}$ \\ From 21st European Pediatric Rheumatology (PReS) Congress \\ Belgrade, Serbia. 17-21 September 2014
}

\section{Introduction}

Serious infections are a major concern in JIA patients treated with immunosuppressants and biologics. Effect of TNF inhibitors on the risk for serious infections and further factors are studied here.

\section{Methods}

Pts exposed to Etanercept (ETA), Adalimumab (ADA) and Methotrexate (MTX) but no biologics and serious infections were identified in the BIKER registry. Descriptive statistics, infection rates, Cox-regression, Hazard ratios (HR) were calculated. Potential risk factors were analysed.

\section{Results}

A total of 3350 pts. with 5929 exposure years were identified in the German BIKER registry data base. First biologic was ETA in 1720 and ADA in 177 cases. 1353 patients were not exposed to biologics. 28 serious infections have been reported (4.7/1000 pt-years). MTX patients had 5 events, Etanercept patients 21 and patients with Adalimumab therapy 2 events.The serious infections were of bacterial origin in 16, viral in 10 and unknown in 2. Total infection incidence per 1000 person years was 4.72 (CI $3.26-6.84$ ). The highest rate was found under ADA (9.73, CI 2.43-38.91) followed by ETA $(8.08$, CI $5.27-12.40)$ and the lowest rate of 1.6 (CI 0.67 - 3.84) with MTX. Univariate Cox regression revealed a number of significant risks for infection, beside therapy $(\mathrm{p}=0.004)$ also JADAS10 at start of therapy, mean JADAS level during therapy, corticosteroids as pre- or concomitant medication as well as MTX and DMARDS as premedication were relevant. In multivariate Cox regression only therapy and mean JADAS10 during observation time remained significant. Both ETA $(\mathrm{HR}=4.88)$ and ADA $(\mathrm{HR}=10.06)$ showed an increased risk compared to MTX, whereas ADA and ETA differed not significally. Risk for infection was significantly increased by an elevated mean JADAS10 level $(\mathrm{HR}=1.12)$. Gender, JIA category, age at start of disease, disease duration, ANA status were not significant. Kaplan Meier analysis confirmed the influence of disease activity as demonstrated by the JADAS10. Table 1 .

Table 1

\begin{tabular}{|c|c|c|c|c|}
\hline Variable & univariate & $\mathrm{HR}(\mathrm{Cl})$ & multivarite & $\mathrm{HR}(\mathrm{Cl})$ \\
\hline $\mathrm{ADA} / \mathrm{MTX}$ & $p=0.022$ & $7.28(1.32-40.04)$ & p00.019 & $10.06(1.67-60.67)$ \\
\hline$\overline{\mathrm{ETA}} / \mathrm{MTX}$ & $p=0.001$ & $5.96(2.03-17.48)$ & $p=0.013$ & $4.88(1.39-17.08)$ \\
\hline More than 1 DMARD failure & $p=0.006$ & $3.06(1.39-6.75)$ & & \\
\hline Pretreatment with steroids & $p=0.007$ & $3.02(1.34-6.77)$ & & \\
\hline Steroids at baseline & $p=0.026$ & $0.418(0.19-0.90)$ & & \\
\hline MTX concomitant & $p=0.001$ & $5.54(2.08-14.71)$ & & \\
\hline JADAS baseline & $p=0.004$ & $1.09(1.03-1.16)$ & & \\
\hline Mean JADAS-level & $p<0.001$ & $1.12(1.05-1.19)$ & $p<0.001$ & $1.12(1.05-1.19)$ \\
\hline
\end{tabular}

\footnotetext{
${ }^{1}$ Asklepios Clinics, Sankt Augustin, Germany
}

Full list of author information is available at the end of the article 


\section{Conclusion}

ETA and ADA treatment as well as higher disease activity contribute to serious infections.

\section{Disclosure of interest}

None declared.

\section{Authors' details}

${ }^{1}$ Asklepios Clinics, Sankt Augustin, Germany. ${ }^{2}$ Institute of Medical Statistics,

Cologne, Germany.

Published: 17 September 2014

doi:10.1186/1546-0096-12-S1-011

Cite this article as: Horneff and Becker: Serious infections in JIA patients upon MTX, TFN inhibitors and combinations. Pediatric Rheumatology 2014 12(Suppl 1):011.

Submit your next manuscript to BioMed Central and take full advantage of:

- Convenient online submission

- Thorough peer review

- No space constraints or color figure charges

- Immediate publication on acceptance

- Inclusion in PubMed, CAS, Scopus and Google Scholar

- Research which is freely available for redistribution

Submit your manuscript at www.biomedcentral.com/submit 